Pótlások egy gyüjteményhez. Az utóbbi hónapokban sürün lapozgattam Reményik Sándor verseinek a Kálvin és a Luther Kiadónál 2012-ben Dávid Gyula szerkesztésében megjelent kétkötetes gyüjteményét, amelynek 2004 októberére keltezett, a többi közt az Evangélikus Egyház Sajtóosztálya, az Orpheus és az Unikornis Kiadó Reményik-köteteit méltató kiadástörténeti összefoglalójában örömmel olvastam a következőket: „Mindhárom utóbb említett kiadásban megjelentek - az Erdélyi Márciusban jelentős számban - a korábbi »összes versek«-ben nem szereplő költemények, részben az egykorú sajtóból, részben a költőnek a Petőfi Irodalmi Múzeumban és a Magyar Tudományos Akadémia Kézirattárában őrzött hagyatékából. Ezt a közel 200 kiadatlan verset is felölelte aztán a Polis Könyvkiadónál megjelent Hátrahagyott versek (Kolozsvár, 2002. Dávid Gyula gondozásában), amely - az egykorú sajtó és a költő hagyatéka módszeres átkutatásával - összesen több mint 400, a korábbi »összes versek«-ből hiányzó Reményik-verssel tette teljesebbé a költőről addig kialakult képet. - Mostani kiadásunk az 1943-as Összes versek és a 2002-es Hátrahagyott versek teljes anyagát tartalmazza."

A teljesítmény, amelyröl a fenti adatok tanúskodnak, lenyűgöző. Éppen ezért örömömet csak kis mértékben mérsékelte, amikor alkalomszerüen kézbe vettem Az Erdélyi Helikon költői (19281944) című antológiát (szerk. Szemlér Ferenc, Bukarest, Kriterion Könyvkiadó, 1973.), s ennek repertóriumában három olyan Reményik-versre bukkantam, amely nemcsak az Erdélyi Helikon évfolyamaiban, hanem az antológiában is fellelhető, a Reményik Sándor Összes verse címü gyüjteményből viszont hiányzik. Ezek a következők:

Szeretnék szeretni $=$ Erdélyi Helikon, 1929, 5, 322. $\rightarrow$ Az Erdélyi Helikon költői, 389-390. Tények = Erdélyi Helikon, 1932, 1, 9. $\rightarrow$ Az Erdélyi Helikon költöi, 394-395.

Lövés = Erdélyi Helikon, 1939, 8, 544. $\rightarrow$ Az Erdélyi Helikon költői, 421-422.

Találtam a repertóriumban egy versciklust is, amelynek 18 számozott darabját a kezdő sorok alapján próbáltam az új kétkötetes Reményik-gyüjtemény verseivel egyeztetni. A kezdő sorok mutatójának hiányában csak a tévedés kockázatával állapíthattam meg, hogy a Hontalan versek címü ciklusból (Erdélyi Helikon, 1938, 9, 649-654.) csupán a 2. és a 9. lelhető fel a Reményik Sándor Összes verse címü gyüjteményben, Hová??, illetve Nagyasszonyunk címmel. A gyüjteményből hiányzó számozott versek címéül kezdő sorukat tüntetem fel:

1. [Az én világom szertehullott...] 649 .

3. [Egy arc. Úristen, el miért veszett...] 650.

4. [A költö és talán az ember...] 650.

5. [Egy sötét kicsi pont az agyban...] 650.

6. [Azt mondjátok, hogy a szinem jó...] 651.

7. [Én mindenkit szerettem...] 651.

8. [Jaj, ha tudnálak megsiratni...] 651.

10. [Rettenetesen szaporodnak...] 651.

11. [Ó, az élök nem boldogok...] 652.

12. [Hiszem az ördögöt...] 652.

13. [Uram, Te ördögöket üztél...] 652.

14. [A gyógyulás rejtett forrása...] 653.

15. [Bizony nem mi kiáltjuk el magunkat...] 653.

16. [Árvák vagyunk...] 653.

17. [Jég vagyok: szeretnék fölengedni...] 653.

18. [Istenem, nem kérek töled nagyot...] 653-654. 
Folytatólag más, kezem ügyébe eső kiadványokat lapozva az egyik marosvásárhelyi folyóirat antológiájában is rábukkantam egy - hadd tegyem hozzá: viszonylag korai, jelentős - Reményik-alkotásra, amely szintén hiányzik a Reményik Sándor Összes verse című gyüjteményből. Adatai:

Az Isten sír. (Madách szellemének.) = Zord Idö, 1921, 4, 158. $\rightarrow$ Zord Idö 1919-1921, Antológia, szerk. Kuti Márta, Marosvásárhely, Mentor Kiadó, 1998, 59-60.

A jelzett hiányok arról árulkodnak, hogy a tiltásokban tobzódó történelmi korszakok kártevései milyen nehezen hozhatók helyre - akár az irodalomban is.

Mutatványként a 2012. évi Reményik-kiadásból hiányzó alkotások közül az Erdélyi Helikon 1938. novemberi számában megjelent Hontalan versek 14. és 16. darabját idézem:

[A gyógyulás rejtett forrása...]

A gyógyulás rejtett forrása

Talán nincs is oly nagyon messze.

Viz-kutató varázs-vesszövel

Orvosok járnak körülötte.

Viz-kutató varázs-vesszövel

Verik földemet orvosok,

Verik, kutatják, jaj de régen-

És én a forrás közvetlen közelében

Szomjan halok.

\section{[Árvák vagyunk...]}

Árvák vagyunk.

Atyánk messze trónol a mennyben,

Csak vergödünk fogvacogtató lázban.

Nincsen egyéb:

Ragadjuk meg egymás kezét

Ebben az óriási árvaházban. 